\title{
Seroprevalence of Bordetella pertussis antibodies among a group of young adults
}

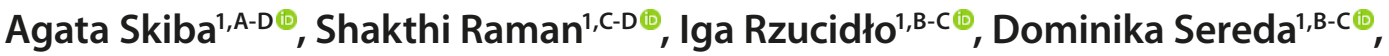 \\ Małgorzata Maria Kozioł2,A,C-F ${ }^{2}$ Chair and Department of Medical Microbiology, Medical University of Lublin, Lublin, Poland
A - Research concept and design, B - Collection and/or assembly of data, C - Data analysis and interpretation,
$D$ - Writing the article, E - Critical revision of the article, F- Final approval of the article \\ ${ }^{1}$ Students Scientific Association at the Chair and Department of Medical Microbiology, Medical University, Lublin, Poland
}

Skiba A, Raman S, Rzucidło I, Sereda D, Kozioł MM. Seroprevalence of Bordetella pertussis antibodies among a group of young adults. J PreClin Clin Res. 2021; 15(3): 126-128. doi: 10.26444/jpccr/141918

\begin{abstract}
Introduction. Bordetella pertussis is a Gram-negative rod which attacks the respiratory system and causes whooping cough disease. Despite the high percentage of childhood vaccination amongst the population an increasing number of pertussis cases have been observed over time, especially among adolescents and young adults.

Objective. The aim of the study was to analyze the concentration of IgG anti-PT Bordetella antibodies in the serum of young adults in the aspect of maintaining immunity.

Materials and method. The study group consisted of 30 patients, medical students aged 21-26 years. They were interviewed with a questionnaire, which asked about their general health, medications taken, basic information about whooping cough, or vaccination status against B. pertussis. The anti-PT Bordetella levels were measured in the collected serum by a commercial ELISA kit (enzyme-linked immunosorbent assay).

Results. All patients had previously received a mandatory vaccination for pertussis as a child, and $36.6 \%$ had received a booster dose after the age of 18 . The total average antibody level was $13.977 \mathrm{IU} / \mathrm{mL}$ (range: $<5.00-50.74$ ) and $40 \%$ of samples had a very low concentration $(<5 \mathrm{IU} / \mathrm{mL})$.

Conclusions. Current findings suggest that post-vaccine immunity decreases over time, while infection susceptibility among younger age groups who have not yet been fully immunized has increased. Methods that could prevent and enable risk stratification of whooping cough include the screening test for anti-PT Bordetella antibody, the improvement of diagnostics, and an additional booster dose.
\end{abstract}

\section{Key words}

whooping cough, antibody level, pertusiss toxin

\section{INTRODUCTION}

Bordetella pertussis is a Gram-negative pathogenic bacterium which causes pertussis, also known as whooping cough. This respiratory disease is highly contagious, and infection is most severe among infants and young children. Due to many virulence factors, the pathogen can easily adhere to and destroy cells of the respiratory epithelium. Two of the most important bacterial biological molecules are pertussis toxin (PT) and tracheal cytotoxin (TCT). The morbidity and mortality of pertussis dropped off sharply after the introduction of a vaccine to the immunization program of the world in 1949, and of Poland in 1960. Despite the persistently high percentage of the vaccinated population, the incidence rates of pertussis increased in the 1990s [1]. Infections in adults and adolescents are recognized more often by general practitioners, despite the fact that whooping cough is commonly considered as a childhood disease [2]. In Poland 12.9 and 17.8 cases per 100000 were noted in 2015 and 2016, respectively, and almost half of them concerned people aged more than 15 years [3]. Increasing numbers of pertussis cases probably indicate decreased immunity, the effectiveness of the vaccine, and the emergence of new

Adress for correspondence: Małgorzata Maria Kozioł, Medical University, Chodzki 1, 20-059 Lublin, Poland

E-mail: malgorzata.koziol@umlub.pl

Received: 14.07.2021; accepted: 03.09.2021; first published: 14.09.2021
B. pertussis strains have also been implicated [1]. Nowadays, two types of vaccines are used to prevent whooping cough: whole-cell vaccine and acellular vaccine. According to the Polish Immunization Program, the whole-cell vaccine should be given in 4 doses in the first months of life (schedule: 2,4 , 6 and around 16 months). The acellular vaccine is used for booster vaccination at 6 and 14 years of age $[4,5]$. It is also recommended for pregnant women as well for newborns with low birth weight. To reduce pertussis cases, a booster dose is recommended every 10 years, given between 19 and 65 years of age $[1,5,6]$.

The period of an effective immune response may be shorter than expected. The activities that would make it possible to prevent and stratify the risk of getting another increase in the incidence of whooping cough seem to be control tests of antiBordetella antibodies, as well as improved diagnostics and re-immunoprophylaxis. The aim of the study was to analyze the concentration of IgG anti-PT Bordetella antibodies in the serum of young adults in the aspect of maintaining immunity.

\section{MATERIALS AND METHOD}

The study group consisted of 30 patients: 20 women (66.6\%) and 10 men (33.4\%), aged 21-26. The patients who reported to the Laboratory of Microbiology in the Chair and Department 
of Medical Microbiology at the Medical University in Lublin, were interviewed with a questionnaire. They were asked about their general health, medications taken, basic information about whooping cough, vaccination status against any history of the disease in their family members. Blood samples were collected and centrifugated to separate the serum. The enzyme-linked immunosorbent assay, ELISA (commercial Euroimmun kit) was used to detect IgG anti-PT antibodies.

\section{RESULTS}

The enrolled group consisted of young people studying medicine. $63 \%$ declared that they develop infections of the upper respiratory tract on average once per year $(p=0.651)$. Only one person had had pneumonia in the last 5 years. In the last year, 21 people (70\%) reported coughing, of whom 16 had cough for only a few days $(p=0.887)$. Most of the respondents had no daily contact with school-age children (83.33\%; $\mathrm{p}=0.93)$. Compulsory immunization against whooping cough was taken by all subjects while a booster dose as a teenager was taken by some of them. Therefore, the students were divided into two groups: Group A- with a booster dose after 18 years of age (11 people; $36.6 \%$ ) and Group B - without booster dose, who did not remember vaccination status (19 people; 63.4\%). Average concetration of IgG anti-PT was $12.707 \mathrm{IU} / \mathrm{mL}$ vs. $14,712 \mathrm{IU} / \mathrm{mL}$. No statistically significant difference was found $(\mathrm{p}=0.486)$.

The seroprevalence of pertussis was at a low level for $86.7 \%$ (26 people) of the study group, and $13.3 \%$ (4 people) presented with an intermediate response. In the enrolled group, $40 \%$ (12 patients) had a result $<5.00 \mathrm{IU} / \mathrm{mL}$ (below detection). The mean antibody titer of all subjects was $13.977 \mathrm{IU} / \mathrm{mL}$ (range: $<5.00-50.74$; SD 15.23). Detailed results of the measurements in the tested sera are presented in Table 1.

Table 1. Laboratory test results of anti-PT Bordetella pertussis (ELISA, Euroimmun kit)

\begin{tabular}{|c|c|c|c|c|}
\hline \multicolumn{5}{|c|}{ Anti-PT Bordetella pertissis ELISA (lgG) } \\
\hline \multirow[t]{4}{*}{$\mathrm{N}=30$} & \multirow{2}{*}{$\begin{array}{c}\geq 100 \mathrm{IU} / \mathrm{mL} \\
\text { Indicate newly } \\
\text { vaccinated }\end{array}$} & \multirow[t]{2}{*}{$99-40 \mathrm{IU} / \mathrm{mL}$} & \multicolumn{2}{|c|}{$\begin{array}{l}<40 \mathrm{IU} / \mathrm{mL} \\
\text { Indicate very low titer }\end{array}$} \\
\hline & & & $5-39 \mathrm{IU} / \mathrm{ml}$ & $<5 \mathrm{IU} / \mathrm{ml}$ \\
\hline & \multirow[t]{2}{*}{$0(0.00 \%)$} & \multirow[t]{2}{*}{$4(13.3 \%)$} & $14(46.7 \%)$ & $12(40 \%)$ \\
\hline & & & \multicolumn{2}{|c|}{$26(86.7 \%)$} \\
\hline \multirow[t]{2}{*}{$\begin{array}{l}\text { antibody } \\
\text { concentration } \\
\text { IU/mL } \\
\text { [International } \\
\text { Units } / \mathrm{mL} \text { ] }\end{array}$} & --- & $\begin{array}{c}\text { av. } 47.699 \\
(43.65-50.74) \\
\text { [SD 2.957] }\end{array}$ & $\begin{array}{c}\text { av.12.037 } \\
(5.063-31.189) \\
{[S D 9.337]}\end{array}$ & $\begin{array}{l}\text { * ‘5.0 IU/ml' } \\
\text { values were } \\
\text { adopted in } \\
\text { the statistical } \\
\text { calculations }\end{array}$ \\
\hline & & & \multicolumn{2}{|c|}{$\begin{array}{c}\text { av. } 8,789 \\
(<5.00-31.189) \\
{[S D 7.624]}\end{array}$} \\
\hline
\end{tabular}

Furthermore, subjects who had very low antibody level, less than $5 \mathrm{IU} / \mathrm{mL}$ (12 patients) include 4 patients from the Group A (students who declared receiving a booster dose of vaccine after 18 years of age). No other differences were noted.

\section{DISCUSSION}

Active immunoprophylaxis by the use of vaccine is the best method to prevent the spread of $B$. pertussis. The percentage of vaccinated infants and children is kept at a high level, which guarantees protection against infection in this age group. However, anti-Bordetella antibodies have been shown to last for approximately 10 years. Immunity after vaccination in young adults is negligible and the recent surge in pertussis cases has been identified by the Centers for Disease Control and Prevention (CDC) as a whooping cough epidemic [6].

Over the years, many studies have been carried out in various European countries to determine population seropositivity. According to the data of Torzs et al., performed in Hungary in 2014-2015, seropositivity $>18 \mathrm{IU} / \mathrm{mL}$ was detected in $14.8 \%$ of healthy adults, while in $85.2 \%$ the antibody titer was too low and did not guarantee an effective immune response [7]. In turn, Jogi et al., scientists from Estonia, ran tests in 2012 among paediatric patients. This age group was expected to indicate a high percentage of patients who were seropositive due to recent compulsory vaccinations. Nevertheless, in $49 \%$ of respondents the antibody concentration was very low, below detectable level $(<5 \mathrm{IU} / \mathrm{mL})$ [8]. Similarly, as our own studies have shown, the percentage of people with titer $<5 \mathrm{IU} / \mathrm{mL}$ was as high as $40 \%$, although it was a group of young adults. It is worth mentioning that one-third of the students from the study group declared that they had received a booster vaccine after 18 years of age. Irrelevant immunoglobulin titer $(<5 \mathrm{IU} / \mathrm{mL})$, but in lower percentage (22.2\%), was also observed by Palazzo et al. in an Italian population of 20-year-olds (aged 20-29), study in 2012-2013) [9]. According to Pavlopoulou et al., $70.7 \%$ of young adults (aged 22-32) in Greece had antibody titer $<20$ FDA U/mL, which was interpreted as seronegative. Most of the study participants (55\%) did not know their immunization status, and $18 \%$ were unvaccinated [10]. Analysis of the collected data of own research demonstrate that all subjects took preventive/ mandatory vaccinations in childhood, and $36.7 \%$ received a booster dose after 18 years of age. However, according to the tests, the mean antibodies serum concentration of them was low and amounted to $12.07 \mathrm{IU} / \mathrm{mL}$, and the concentration range was wide: $<5-43.658 \mathrm{UI} / \mathrm{mL}$ (SD: 12.79 ). At the same time, no statistical significance was demonstrated in this range.

Comparing and interpreting the results may be difficult due to the size of the study groups, the variety of tests used in the study, and the type of vaccine given previously to the participants. It has also not been established whether the determination of only IgG anti-Bordetella antibodies is sufficient to determine the presence of protection against infection. The immune response against pertussis is multifactorial and involves $\mathrm{T}$ and $\mathrm{B}$ lymphocytes. However, antibodies directed against pertussis toxin are a good marker due to their specificity and lack of cross-reactivity with other antigens [8].

The results obtained in many studies suggest that immunization provides immunity among children, but that the levels of circulating antibodies decline rapidly, thus young adults are already susceptible to infection with $B$. pertussis. This age group becomes a source of the pathogen that poses a threat to newborns and children not yet immunized. Providing booster doses of vaccine among adults could limit the spread of the microorganism. Another proposed solution 
to protect infants is that women should vaccinate themselves before/during pregnancy. The produced maternal antibodies would significantly reduce the risk of infection in newborn babies $[9,11,12]$. The activities that would also improve prevention and risk stratification seem to be control screening tests for anti-PT Bordetella, more detailed understanding of the immune response mechanisms, as well as improved diagnostics are needed.

\section{CONCLUSIONS}

Whooping cough caused by Bordetella pertussis is commonly referred to as a 're-emerging disease', and the observation of own research, in correlation with the data of other researchers, outlines the very high risk of its recurrence. Considering adults participate in the transmission of the pathogen, our study has shown that $86.7 \%$ of young adults have a low antibody titer, while over one-third declared that they had received a booster vaccination. This proves a significant reduction of the immunoprotection period in adulthood. It seems crucial to develop a vaccine that will ensure an extended period of immunity after vaccination. At the same time, additional vaccinations among adults could limit the transmission of the microorganism.

\section{REFERENCES}

1. Prygiel M, Mosiej E, Zasada AA. Przyczyny wzrostu zachorowalności na krztusiec. Postępy Mikrobiol. 2020; 59(1): 11-24.
2.Libster R, Edwards KM. Re-emergence of pertussis: what are the solutions? Expert Rev. Vaccines 2012; 11(11): 1331-1346. doi: 10.1586/ erv.12.118

3. Rumik A, Paradowska-Stankiewicz I, Rudowska J, et al. Krztusiec w Polsce w 2017 roku. Przegl Epidemiol. 2019; 73(6): 289-295.

4. Nieves DJ, Heininger U. Bordetella pertussis. Microbiol. Spectrum 2016; 4(3): 274-75. doi: 10.1128/microbiolspec.EI10-0008-2015

5. Maryland Department of Health, "Local Health Department Guidelines for the Epidemiological Investigation and Control of Pertussis (Whooping Cough)," no. February, 2018, [Online]. Available: https:// phpa.health.maryland.gov/IDEHASharedDocuments/Pertussis Investigation Guidelines Revised February 2018 Final-ES.pdf.

6. Ebell MH, Marchello C, Callahan M. Clinical diagnosis of Bordetella pertussis infection: Asystematic review. J Am Board Fam Med. 2017; 30(3): 308-319. doi: 10.3122/jabfm.2017.03.160330

7. Torzsa P, Devadiga R, Tafalla M. Seroprevalence of Bordetella pertussis antibodies in adults in Hungary: Results of an epidemiological crosssectional study. BMC Infect Dis. 2017; 17(1): 242. doi: 10.1186/s12879017-2356-2. PMID: 28376739

8. Jõgi P, Oona M, Toompere K, et al. Seroprevalence of IgG antibodies to pertussis toxin in children and adolescents in Estonia. Vaccine 2014; 32(41): 5311-5315. doi: 10.1016/j.vaccine.2014.07.066

9. Palazzo R, Carollo M, Fedele G, et al. Evidence of increased circulation of Bordetella pertussis in the italian adult population from seroprevalence data (2012-2013). J Med Microbiol. 2016; 65(7): 649-657. doi: 10.1099/ jmm.0.000264

10. Pavlopoulou ID, Syriopoulou V, Daikos GL, et al. Pertusssis seroprevalence in different age groups in Greece. Scand J Infect Dis. 2007; 39(1): 14-18. doi: 10.1080/00365540600891299

11. Eberhardt CS, Siegrist CA. What Is Wrong with Pertussis Vaccine Immunity? Cold Spring Harb. Perspect Biol. 2017; 9(12): a029629. doi: 10.1101/cshperspect.a029629

12. Sompagdee N, Anuwutnavin S, Phongsamart W, et al. Seroprevalence of Bordetella pertussis antibodies and anti-pertussis antibody response after a single dose of reduced-antigen combined diphtheria, tetanus, and acellular pertussis vaccine (Tdap) in pregnant Thai women. Vaccine 2020; 38(12): 2725-2733. doi: 10.1016/j.vaccine.2020.01.074 